\title{
The middle class in contemporary South Africa: Comparing rival approaches
}

RONELLE BURGER, CINDY LEE STEENEKAMP, SERVAAS VAN DER BERG AND ASMUS ZOCH

\section{Stellenbosch Economic Working Papers: 11/14}

\author{
KEYWORDS: MIDDLE CLASS, SOCIAL CLASS, SOUTH AFRICA \\ JEL: D31, I31. J 15
}

$\begin{array}{cc}\text { RONELLE BURGER } & \text { CINDY LEE } \\ \text { DEPARTMENT OF } & \text { STEENEKAMP } \\ \text { ECONOMICS } & \text { DEPARTMENT OF } \\ \text { UNIVERSITY OF } & \text { POLITICAL SCIENCE } \\ \text { STELLENBOSCH } & \text { UNIVERSITY OF } \\ \text { PRIVATE BAG X1,7602 } & \text { STELLENBOSCH } \\ \text { MATIELAND, SOUTH } & \text { PRIVATE BAG X1,7602 } \\ \text { AFRICA } & \text { MATIELAND, SOUTH } \\ \text { E-MAIL: } & \text { AFRICA } \\ \text { RBURGER@SUN.AC.ZA } & \text { E-MAIL: } \\ & \text { CINDYLEE@SUN.AC.ZA }\end{array}$

ASMUS ZOCH DEPARTMENT OF ECONOMICS UNIVERSITY OF STELLENBOSCH PRIVATE BAG X1, 7602 MATIELAND, SOUTH AFRICA E-MAIL: ASMUSZOCH@GMAIL.COM
SERVAAS VAN DER BERG DEPARTMENT OF ECONOMICS UNIVERSITY OF STELLENBOSCH PRIVATE BAG X1, 7602 MATIELAND, SOUTH AFRICA E-MAI L: SVDB@SUN.AC.ZA




\title{
The middle class in contemporary South Africa: Comparing rival approaches
}

\author{
Ronelle Burger ${ }^{1}$, Cindy Lee Steenekamp ${ }^{2}$, Servaas van der Berg ${ }^{3} \&$ Asmus Zoch ${ }^{4}$
}

In the light of the economic, political and social significance of the middle class for South Africa's emerging democracy, we critically examine contrasting conceptualisa-tions of social class. We compare four rival approaches to empirical estimation of class: an occupational skill measure, a vulnerability indictor, an income polarisation approach and subjective social status.

There is considerable variation in who is classified as middle class based on the definition that is employed and, in particular, a marked difference between subjective and objective notions of social class. We caution against overoptimistic predictions based on the growth of the black middle class. While the surge in the black middle class is expected to help dismantle the association between race and class in South Africa, the analysis suggests that notions of identity may adjust more slowly to these new realities and consequently, racial integration and social cohesion may emerge with a substantial lag.

Keywords: middle class, social class, South Africa

JEL: D31, I31. J15

\section{Introduction}

Apartheid has left its scar on South Africa's social landscape. Almost two decades after the first fully inclusive elections in 1994, society continues to be characterised by a lack of social cohesion and economic injustice due to the persistence of race as a marker and a sorting mechanism in many dimensions of daily life, including geographical space, educational opportunities, the labour market, social networks and political party affiliation.

However, recent analysis suggests that there has been rapid growth in the middle class in the postapartheid period, but also that the black share of the middle class has increased dramatically over this period, indicating that gradually race may be becoming disassociated from class. This is seen as a significant development because a growing and more racially representative middle class can help shape a more just, dynamic and integrated society. Theory and previous empirical findings suggest that an expanding middle class can boost economic efficiency and growth, enhance the effectiveness and the stability of democratic institutions and political processes and can help to mend social fragmentation and polarisation. There are also arguments that a growing middle class can have a direct impact on social cohesion, seemingly based on the intuition that a larger middle group would often imply lower polarisation and would serve as a buffer between the rich and the poor.

\footnotetext{
${ }^{1}$ Department of Economics, University of Stellenbosch. Corresponding author: email: rburger@sun.ac.za

${ }^{2}$ Centre for International and Comparative Politics, Department of Political Science, University of Stellenbosch

${ }^{3}$ Department of Economics, University of Stellenbosch

${ }^{4}$ Department of Economics, University of Stellenbosch
} 
Within the South African context it is of course significant that a large share of the new middle class members is non-white: both from a retrospective viewpoint, as evidence that some of the postapartheid reforms have been successful in creating a more just and dynamic society, but also from a prospective viewpoint, as a catalyst for further social change.

Due to the economic, political and social significance of class for South Africa's emerging democracy, it is important and interesting to estimate the magnitude of the growth of the middle class and specifically, the black middle class - and to understand what this means. However, such attempts are frustrated by disputes around the origins and meaning of class and how it should be measured. Lopez-Calva and Ortiz-Juarez (2011:1) highlight that empirical work on the middle class tends to assume that 'thresholds that define relatively homogeneous groups in terms of pre-determined sociological characteristics can be found empirically'. Research on the middle class is often motivated by an interest in the political, economic and social benefits associated with the term, but without verifying whether the selected empirical approach is aligned with such conjectured benefits.

Using hyperbole and humour to highlight the proliferation of competing conceptualisation of the middle class, Beckett (2010:1) refers to it as 'a slippery business' that has in the past been associated with a long and divergent list of characteristics, including 'having servants, renting a good property, owning a good property, owning a business, being employed in one of the professions, how you speak, how you use cutlery' (2010:1). This article acknowledges the contradictions and tensions in the menu of definitions and methods available for approximating the size of the middle class. It pursues a more critical and conceptually-grounded approach. It presents a brief, but critical overview of contrasting conceptualization of class and how this has affected studies on class in South Africa. We describe and implement the four main empirical approaches using the 2008 National Income Dynamics Study (NIDS), noting the overlaps and tensions between these estimates. This analysis is supplemented by work on the World Values Survey for South Africa in 2006 (WVS), considering patterns in self-identification as middle class members. We compare the cross-section estimates and trends over time yielded by these four rival approaches and discuss the origins of the discrepancies.

\section{Estimating the size of the middle class in South Africa}

The analysis of class owes much to the pioneering work of Karl Marx and Max Weber. Marx defines class as shared structural positions within the social organisation of production. His approach is embedded in a social-psychological perspective with class originating from shared interests and economic position. The focus is on a conflict between the two main social classes, bourgeoisie (upper class) and proletariat (lower class). The bourgeoisie owns or controls the means of production (physical capital) while the proletariat does not and therefore needs to sell their labour to the bourgeoisie. Marx also distinguished a third class of petty bourgeoisie, which can be seen as a middle class. They are typically small business owners, shop-keepers, artisans and managers who are similar to the bourgeoisie because they are able to control (but not necessarily own) the means of production, but differ from the haute bourgeoisie because they work alongside their staff. Marx saw this group as a transitional class, which would eventually be absorbed into the proletariat. 
In contrast, Max Weber offers a structural-functionalist view of class as shared life chances, with life chances associated with opportunities for generating income in the market. Similar to Marx he also differentiates between those with access to property and land and those without, who have to earn their living through work. For those without property, their education, skills and knowledge determine their market value, their occupation and their wages and in turn, wages determine the life style that an individual can afford. In this way economic position maps to social status and shapes shared interests and social communities. However, while economic power, social status and political power are often correlated, Weber diverges from Marx by recognising that social status and political power are separate dimensions that are not always aligned with economic position and power. According to Weber, differences in social status can emerge due to ownership of the mean of production, but it can also emerge due to other factors such as skills or credentials (Seekings, 2009).

Weber also distinguished the established class of property owners from the emergent middle class who were white-collar employees without property. However, in contrast to Marx who saw this class as a temporary or transitional class that will eventually be absorbed into the proletariat, Weber expected the increasing bureaucratisation of administration to enhance the importance of specialist examination, creating a "universal clamour for the creation of educational certificates in all fields" and leading to "the formation of a privileged stratum in bureaus and offices" (1961:241).

The concept of class has evolved much since the days of Karl Marx and Max Weber, but education, social status, income, wealth and shared life perspectives have remained central to definitions of class. One of the main enduring tensions is whether education or income is at the heart of the definition of class and the main transmission mechanism for the benefits of a growing middle class (Mattes, forthcoming).

Despite debates around the relevance of the concept of class ${ }^{5}$ in current times, the term "middle class" has continued to be popular amongst both researchers and the media. Recently, it has often been used to gauge the pace of social change and economic advancement in emerging and developing economies. In this literature the term "middle class" is frequently used as shorthand for increased agency and empowerment that allow individuals to competently navigate their own destinies and realise their own potential.

The term's enduring popularity and continued prominence appear to be partly due to a significant literature linking the middle class to a range of desirable country-level outcomes such as social cohesion, political stability and economic growth. Although authors are seldom explicit about the transmission mechanisms for such benefits, there are several analytical linkages, including appeasement of the poor, increasing discretion in the use of money and time as basic needs are met, and a longer planning horizon due to greater stability in living standards. The combination of more discretionary income and a longer time horizon is expected to encourage investment in physical and human capital - both of which are traditionally viewed as important for stimulating economic growth because they improve productivity - and to enable the middle class to be more

\footnotetext{
${ }^{5}$ There have been arguments that the concept is outdated. For instance, Pakulski (2005) argues that the complex configurations of classless inequality and antagonism call for more comprehensive theoretical and analytic constructs.
} 
active and vocal in promoting accountability, good governance and the prioritisation of public goods such as education (Birdsall, 2010). Mattes (forthcoming) distinguishes three different theories about how a larger middle class can strengthen democracy: through a more educated and skilled public sector work force; via the relationship between education and civic values; or by allowing a focus on free speech, civil liberties and democracy when basic needs have been met.

The interest in South Africa's social structure in general and the middle class in particular has spawned a large literature, much of which has had a strong Marxist focus. Seekings (2009) points out that there were a number of Weberian scholars working on class in South Africa between the late forties and the early seventies, but that this stream of work was abandoned and subsequently forgotten due to apartheid-era political considerations and sentiments that favoured a Marxist approach. The dominance of the Marxist approach led to the neglect of the relationship between class and Weberian concepts such as skill and social status. Although not explicitly Weberian, more recent research tends to highlight the role of Weberian concepts such as education and consumption (e.g. Rivero et al, 2003; Schlemmer, 2005; Seekings and Nattrass, 2005; Nieftagodien and Van der Berg, 2007; Seekings, 2007; Udjo, 2008; and Visagie and Posel, 2011) .

There is consensus amongst the more recent studies that the middle class is expanding and that there has been a significant increase in the black share of the middle class (e.g. StatsSA, 2009; Van der Berg, 2010). While this growing disassociation between race and class has the potential to promote political stability and social cohesion, Schlemmer (2005) concludes that the racial divide is still conspicuous - especially in areas where racial interests diverge, such as party politics, affirmative action and privatisation. He finds few close personal links across the racial divide. He also reports that there is no cohesive identity and coherence amongst the emergent black middle class. Many appear uncomfortable with the label and are reluctant to identify themselves as middle class.

Our analysis attempts to add to this existing literature by comparing rival conceptualizations of the middle class and assessing the overlaps and tensions between these definitions when applied to recent and representative South African data sets. In particular, in the light of Schlemmer's (2005) findings, we examine how well traditional externally defined measures of class align with individuals subjective notions of their social position and class identity.

\section{Data}

Our analysis relies mainly on the 2008 NIDS data. This is the only recent data set that is rich enough to cover all the relevant dimensions required to allow a comparison of the four main empirical approaches. The surveys include 31163 individual observations and 6921 households in 2008 and 35210 individual observations and 9170 households for 2010.

The survey contains detailed information on occupation, income and expenditure and an extensive list of assets. It also has information regarding where individuals saw themselves on the income ladder, which can be used to gauge how well the individual's perception of their economic position matches their actual position. We also use the subsequent two waves of NIDS $(2010,2012)$ for implementing the vulnerability approach (which requires panel data) and for comparing trends across time with these four approaches. We include the Project for Statistics on Living Standards and 
Development (PSLSD) of 1993 in the trend analysis where it was sufficiently comparable with the data from the three NIDS surveys. ${ }^{6}$

The second data source is the last four waves $(1995,2001,2006,2013)$ of the World Value Surveys. Each of the waves of the survey has a sample of approximately 3000 individual observations. While this is a smaller sample than NIDS, it offers considerable additional depth in terms of the values, attitudes and social behaviour of individuals. The WVS also contains information on occupations and assets and although the income data is less detailed (using income brackets), it includes information on self-identified class and on the values and attitudes of individuals, which will allow us to look at self-reported membership of the middle class and to examine whether class has a significant and strong association with values and attitudes.

\section{Comparing rival approaches to estimating the middle class}

Attempts to identify and study the middle class with survey data often make prominent reference to the country-level benefits associated with a growing middle class when outlining the rationale for the research, but then largely disregard existing theories of the middle class that could explain such links. Consequently, the large body of empirical studies has developed largely divorced from the theoretical literature.

Four approaches have emerged as the leading empirical techniques for estimating the middle class: income or expenditure measures, the vulnerability approach, the occupational approach and selfassessment. These approaches will be discussed in more detail below and implemented to derive estimates of the size of the middle class in contemporary South Africa.

\subsection{Occupation and skill level}

There is a long standing tradition of class analysis based on occupation and skill level (see e.g. Carlsson, 1958; Goldthorpe, 1987; Wright, 1980; Edgell and Duke, 1991; Goldthorpe and Erikson, 1993; Evans and Millan, 1999) and consequently a fair degree of consensus has emerged regarding what occupations constitute the middle class (e.g white-collar workers such as professionals, managers and clerks). However, some disputes remain about whether the middle class should include the self-employed (Wright, 1989:5; Wright, 1979; Glassman et al. 1993).

One of the problems with the occupational approach to approximating class is that questions on occupation are frequently left unanswered or not answered well in survey data. However, the occupation variable is sufficiently reliable to provide a broad overview of the prevalence of middle class occupations and its interaction with other variables of interest such as race, age and education. There is also risk that in settings with high unemployment rates and significant levels of underemployment, there may be a divergence between the productive characteristics and abilities of individuals and their occupation, as analysis reliant on occupation can only classify individuals who are currently employed (Seekings and Nattrass, 2005). Additionally, class analysis uses the household

${ }^{6}$ For NIDS we use year weights and the unbalanced panel, except for the vulnerability model, where we are restricted to the balanced panel for the estimation of the coefficient, but then apply these estimates to the entire sample. 
as its unit of analysis, but members from the same household may have occupations that are categorised as belonging to different classes. Ceruti (2013) points out that individuals' class position could be mediated via the life chances and living standards of those with whom they share a home.

In using the NIDS data we navigate our way through the issues outlined above by implementing a definition of occupational class which has four broad classifications: unemployed, low skill, medium skill and high skill. The low skill category comprises the so-called elementary occupations and includes domestic, agricultural and fishery workers. The medium skill category is defined as clerks, service workers and shop and market, craft and related trades workers, plant and machinery operators and assemblers, while the high skill category includes legislators, senior officials and managers, professionals, technicians and associated professions.

Due to high unemployment rate in South Africa a large segment of the self-employed enter this sector because they cannot find salaried employment. The self-employed will therefore not be an elite group (as a Marxian analysis will often assume), but will include both highly skilled and unskilled individuals. The self-employed are therefore classified based on their occupations, in the same way as regular employees. We convert individual level occupational skill variables to a household variable by using the highest occupational skill level of any household member to classify households.

The categorisation of the unemployed also presents a challenge. Seekings (2003) argues that in South Africa the unemployed constitute an underclass both because of the size of this group and the substantial divide between the unemployed and the employed in terms of their living conditions. However, Seekings and Nattrass (2005) point out that there is considerable variation in the labour market prospects among the unemployed, including for instance skilled individuals from affluent households using unemployment as a waiting bay for the right opportunity. It may therefore be useful to distinguish amongst the unemployed between an underclass that is a disadvantaged and marginalised subsection of the unemployed with long unemployment duration, low social capital, little wealth and low skills and often living in a remote location, and others who may be in more affluent households. As the highest occupational skill category is used to classify the household, this should not be too great an issue". 
TABLE 1: Characteristics of classes when categorised based on occupational skill levels, 2008

\begin{tabular}{|l|c|c|c|c|c|c|c|}
\hline Class & $\begin{array}{c}\text { Share of } \\
\text { total } \\
\text { popula- } \\
\text { tion }\end{array}$ & $\begin{array}{c}\text { Share of } \\
\text { black } \\
\text { popula- } \\
\text { tion }\end{array}$ & $\begin{array}{c}\text { Share of } \\
\text { white } \\
\text { popula- } \\
\text { tion }\end{array}$ & $\begin{array}{c}\text { Black } \\
\text { share of } \\
\text { each class }\end{array}$ & $\begin{array}{c}\text { Mean } \\
\text { income }\end{array}$ & Mean age & $\begin{array}{c}\text { Mean } \\
\text { education } \\
\text { al attain- } \\
\text { ment }\end{array}$ \\
\hline Unemployed & 14.0 & 16.1 & 5.2 & 86.7 & R 1 965 & 33.1 & 8.9 \\
\hline Low skilled & 23.8 & 26.1 & 11.8 & 82.7 & R 4 004 & 39.7 & 7.5 \\
\hline $\begin{array}{l}\text { Medium } \\
\text { skilled }\end{array}$ & 29.9 & 30.9 & 21.5 & 78.0 & R 5 791 & 35.3 & 9.9 \\
\hline $\begin{array}{l}\text { Highly } \\
\text { skilled }\end{array}$ & 15.5 & 10.1 & 40.2 & 49.1 & R 17 280 & 39.1 & 12.8 \\
\hline $\begin{array}{l}\text { No } \\
\text { information } \\
\text { on skill }\end{array}$ & 16.8 & 16.8 & 21.4 & 75.4 & R3 040 & 52.1 & 6.7 \\
\hline
\end{tabular}

Source: NIDS 2008. Household classifications are based on the highest skill level within the household. The mean age and education attainment relates to the household member with the highest occupational skill level.

Table 1 illustrates that the low skilled and medium skilled occupational classes combined represent the majority (53\%) of all South African households. The low skilled occupational class represents roughly $24 \%$, the medium skilled occupational class $29 \%$ and the two tails of the distribution (the highly skilled and the unemployed) both roughly $15 \%$ of the population. Table 1 also shows that higher skilled occupations are associated with higher income levels and educational attainment. The middle skill level occupations have a much lower mean age of 34 compared to the mean age of 40 for lower skill level occupations and 39 for higher skill level occupations. Blacks constitute $87 \%$ of the unemployed, $82 \%$ of households associated with lower skill occupations, $78 \%$ of households with medium skill occupations and $49 \%$ of households with high skilled occupations.

\subsection{Vulnerability}

Goldthorpe and McKnight (2004) find that class is correlated with the risk and uncertainty faced by individuals, mediated via the relationship between secure employment contracts, labour market negotiating power and skill scarcity. Following from this, Lopez-Calva and Ortiz-Juarez (2011) propose a vulnerability approach to estimating the middle-class because they argue that not all nonpoor households are middle-class: Some still face considerable vulnerability and risk of sliding downwards, into poverty. This approach resonates with previous findings on the country-level benefits of a growing middle-class, because reduced risk and lower volatility map to middle class characteristics such as a longer planning horizon (and associated savings and human capital investment decisions) and financial independence. Furthermore, risk represents an emotional burden and managing it on a day-to-day basis is a taxing activity that diverts energy away from other pursuits.

The vulnerability approach requires panel data to estimate the likelihood of falling into poverty based on a range of variables, including service delivery indicators such as access to running water as well as socioeconomic characteristics of the head of the household such as educational attainment, employment status, gender and age. This approach uses the likelihood of falling into poverty to categorise households. The middle class is defined as non-poor households who have a low 
probability of falling into poverty but who are still below an affluence threshold. However, it is difficult to accurately predict vulnerability and the dependence on panel data restricts the use of this approach. It is also problematic that any comparison over time requires the implementation of the same underlying structural model, because one of the key purposes of trend analysis would be to look at how the distribution of characteristics or the shares of vulnerable subgroups may have changed over time. On the other hand, the integration of multiple dimensions of deprivation is a key strength of this approach.

To apply the vulnerability approach we make use of the panel element of the NIDS data set. Using two different poverty lines, we run probit regressions to estimate the likelihood of each household to remain in poverty or fall into poverty in the second wave of NIDS 2010. Following Argent et al. (2009) we use per capita income of R502 as the poverty line. Classes are defined based on the probability that a household will be non-poor in 2010 based on 2008 characteristics such as unemployment status, age of the household head (and its square), education of the household head (and its square), whether the household head is black, whether the household head is female, household size and an asset index ${ }^{7}$. Households are defined as lower class if the probability of becoming non-poor in 2010 is below 10\%, vulnerable if the probability is between $10 \%$ and $50 \%$, middle class if the probability is between $50 \%$ and $90 \%$ and upper class if the probability is above $90 \%$.

TABLE 2: Characteristics of classes when categorised based on vulnerability approach, 2008

\begin{tabular}{|l|c|c|c|c|c|c|c|}
\hline Class & $\begin{array}{c}\text { Share of } \\
\text { total } \\
\text { population }\end{array}$ & $\begin{array}{c}\text { Share of } \\
\text { black } \\
\text { population }\end{array}$ & $\begin{array}{c}\text { Share of } \\
\text { white } \\
\text { population }\end{array}$ & $\begin{array}{c}\text { Black } \\
\text { share of } \\
\text { each } \\
\text { class }\end{array}$ & $\begin{array}{c}\text { Mean } \\
\text { income }\end{array}$ & $\begin{array}{c}\text { Mean } \\
\text { age }\end{array}$ & $\begin{array}{c}\text { Mean } \\
\text { educational } \\
\text { attainment }\end{array}$ \\
\hline Lower class & 22.6 & 28.3 & - & 98.1 & $R 323$ & 38.1 & 6.4 \\
\hline $\begin{array}{l}\text { Vulnerable } \\
\text { class }\end{array}$ & 37.5 & 45.5 & 0.2 & 95.2 & $R 639$ & 38.2 & 7.5 \\
\hline Middle class & 26.8 & 23.8 & 22.6 & 69.7 & R1925 & 36.5 & 9.9 \\
\hline Upper class & 13.1 & 2.4 & 77.3 & 14.6 & R7308 & 43.0 & 12.7 \\
\hline
\end{tabular}

Source: NIDS 2008 and 2010. Based on the predicted probability of a household to be non-poor in 2010 households are classified as lower class (probability<10\%); vulnerable (10\%-50\%); middle class $(50-90 \%)$; upper class $(>90 \%)$. The mean age and education attainment relates to the household member with the highest occupational skill level.

We find that $23 \%$ of households are very likely to be poor in both 2008 and 2010 and therefore considered to be chronically poor and belong to the lower class. Table 2 also shows the strong association between race and class when applying the vulnerability approach. Almost $30 \%$ of black South Africans are categorised as lower class, a further $46 \%$ belong to the vulnerable class, $24 \%$ to the middle class and only $3 \%$ are categorised as upper class. In contrast, there are virtually no whites

\footnotetext{
7 The asset index is estimated using the multiple correspondence analysis command in Stata, based on variables relating to various aspects of the household's living conditions including access to water and sanitation and the energy sources used for lighting, heating and cooking, access to credit, home ownership and a long list of household possessions. The list of household possessions include car ownership, owning a TV, microwave, radio, satellite, VCR, computer, camera, electric stove, gas stove, microwave, fridge, washing machine, sewing machine, knitting machine, lounge suite, motorcycle, plough, tractor, wheelbarrow and grinding mill.
} 
amongst the lower classes and the vulnerable, but $23 \%$ of white South African are categorised as middle class and $77 \%$ as upper class.

\subsection{Income}

Income is often used to estimate class because it provides a measure of an individual's economic power and is viewed as a correlate of social status because it determines a household's buying power and reflects market value and negotiating power in the labour market. Because income is a continuous variable, classes are defined using cut-off values of income. In economics, the middle class is often defined as a residual category, distinct from the lower classes (or the poor) and the upper class (or the affluent), therefore two cut-off points are required. Such points are usually defined based on percentiles, median or mean values or alternatively, absolute thresholds.

Class can be defined using fixed percentages of the income distribution. For instance, Easterly (2001) defines the bottom $20 \%$ as lower class and the top $20 \%$ as upper class, thus categorising the remaining $60 \%$ as the middle class. One can also define poverty and affluence lines respectively as a share and multiple of a mean or median income. Birdsall, Graham, and Pettinato (2000) define the middle class as those with income between 0.75 and 1.25 of median per capita income. Alternatively, we can use a poverty line set at a specific level of per capita income as the cut-off to distinguish the middle class from the poor and similarly, a line of affluence to distinguish the middle class from the affluent. This approach is sometimes preferred above the relative measures reliant on percentiles and medians because it allows comparisons with other countries.

However, all of these approaches remain vulnerable to the criticism that their thresholds are arbitrary $^{8}$; therefore we opt for a polarisation method developed by Esteban, Gradín and Ray (1999) to find homogenous social clusters using the underlying concepts of identification and alienation. The authors argue that traditional approaches utilising arbitrary cut-offs often result in groups without any internal cohesion and where there are considerable variation in characteristics. This is likely to be a risk when applying arbitrary thresholds to South Africa's fragmented and unequal social landscape where there is little evidence of a large cohesive core. By using the patterns in the data to identify clusters and to make decisions about natural breaks and cut-offs, the polarisation method is more responsive to the anomalies and atypical features of South Africa's income distribution and therefore offers a more appropriate approach to identifying a reasonably homogenous and cohesive middle class within such an unequal and divided society.

While this polarisation approach addresses the concern about the arbitrary cut-offs, there are also more fundamental objections against using income-based measures of class. There are concerns that income is too narrow and fluctuates too much to fully capture and reflect prospects and life chances (Torche and Lopez-Calva, 2011). This might be particularly relevant for developing countries, where the income of low and semi-skilled labourers and the self-employed can vary greatly over seasons. Atkinson and Brandolini (2011) compare a series of income-based estimation of class with indicators of wealth, property ownership and occupation for fifteen countries included in the

\footnotetext{
${ }^{8}$ The cost of a minimum basket of goods required for survival can justify the choice of a poverty line, but the definition of the affluence line remains arbitrary and thus this approach remains exposed to the criticism of arbitrary cut-off points. See Atkinson and Brandolini (2011) for a more comprehensive treatment of the problems with alterative income approaches to the estimation of class and the consequent preference for the polarisation approach.
} 
Luxembourg Income Study and the Luxembourg Wealth Study around 1985 and 2004. They find that the income-based class estimates often include heterogenous groups with very different life chances, and highlight the inadequacies of a definition of class that is entirely reliant on income in the presence of capital market imperfections and public income support.

TABLE 3: Characteristics of classes when categorised using the income polarization approach, 2008

\begin{tabular}{|c|c|c|c|c|c|c|c|}
\hline Class & $\begin{array}{c}\text { Share of } \\
\text { total } \\
\text { popu- } \\
\text { lation }\end{array}$ & $\begin{array}{c}\text { Share of } \\
\text { black } \\
\text { popu- } \\
\text { lation }\end{array}$ & $\begin{array}{c}\text { Share of } \\
\text { white } \\
\text { population }\end{array}$ & $\begin{array}{c}\text { Black } \\
\text { share of } \\
\text { each class }\end{array}$ & $\begin{array}{c}\text { Mean } \\
\text { income }\end{array}$ & Mean age & $\begin{array}{c}\text { Mean } \\
\text { educa- } \\
\text { tional } \\
\text { attain- } \\
\text { ment }\end{array}$ \\
\hline Lower class & 60.6 & 70.7 & 4.7 & 92.2 & R376 & 37.7 & 7.6 \\
\hline Middle class & 28.5 & 25.2 & 31.7 & 69.8 & R1763 & 38.4 & 9.6 \\
\hline Upper class & 10.9 & 4.1 & 63.7 & 29.4 & R9574 & 43.1 & 12.5 \\
\hline
\end{tabular}

Source: NIDS 2008. The classification of classes is based on the polarization approach as described in Esteban, Gradin and Ray (1999). The mean age and education attainment relates to the household member with the highest occupational skill level.

As expected, Table 3 shows large gaps in the mean income per capita of lower, middle and upper class households of R376, R1763 and R9573 respectively. The mean educational attainment of the highest skilled individual in the household varies according to class: it is 7.6 years for the lower classes, 9.6 years for the middle class and 12.5 years for the upper class. Both the lower and the middle classes are predominantly black ( $92 \%$ and $70 \%$ respectively), but the black share of the upper class is only $29 \%$. One in four blacks are middle class.

\subsection{Self-identification or subjective social class}

Perceptions of individual ranking and social standing have long interested sociologists. Theorists such as a Marx (Marx, 1844 and 1972; Marx and Engels, 1968: 37) and Durkheim (1933) assumed that individuals knew their position in society and that there was an alignment between objective and subjective social status. ${ }^{9}$ In contrast, the reference-groups hypothesis raises the possibility that there may be a divergence between objective and subjective social class. It acknowledges that an individual's perceptions of their place in the social hierarchy are largely formed by the circle of their close acquaintances (Stouffer, Suchman, de Vinney, Star and Williams, 1949).

The crux of the argument is that the homogeneity of reference groups - the assortative tendency to surround oneself with friends with similar education, occupation and income - fundamentally distorts the subjective sample from which one generalises to the wider society and from which one develops perceptions of one's subjective location. Taken together, these lead to images of society with few at the top, the great majority in the middle, and few at the bottom. In this view,

\footnotetext{
${ }^{9}$ Marx holds that the objective conditions of production in capitalist society lead workers to recognise that they are at the bottom of the social hierarchy, which is increasingly clarified as economic growth magnifies the luxuries of those at the top. Similarly, Durkheim (1933: 187-190; 256-263) shared Marx’s assumption that objective circumstances translate directly into subjective perceptions, but anticipated different objective conditions: urbanisation, population increase, and economic growth would expand the demand for skilled and educated workers thereby expanding the middle of the social hierarchy, while thinning the extremes, creating a society with few at the top, many in the middle, and leaving many at the bottom - but not as many as in the Marxian image.
} 
perceptions of the shape of the social stratification system and of one's place in it are only loosely linked to objective circumstances, since objective conditions are filtered through the lens of reference groups.

We examine these theories by investigating self-identified social position using the NIDS data. All adult respondents were asked to imagine a six step ladder with the poorest people in South Africa on the bottom or first step and the richest people standing on the top or sixth step. Respondents were then asked on which rung of the income ladder they saw their household. While the terms poor and rich would conventionally be interpreted in a narrow sense as referring to income, there is room for broader interpretations, especially given the use of the ladder metaphor. We create a comparable household level variable of class by applying the self-identified social position of the household member with the highest skill level to the household.

TABLE 4: Characteristics of classes when categorised using self-reported assessment, 2008

\begin{tabular}{|c|c|c|c|c|c|c|c|}
\hline Class & $\begin{array}{c}\text { Share of } \\
\text { total } \\
\text { popu- } \\
\text { lation }\end{array}$ & $\begin{array}{c}\text { Share of } \\
\text { black } \\
\text { popu- } \\
\text { lation }\end{array}$ & $\begin{array}{c}\text { Share of } \\
\text { white } \\
\text { population }\end{array}$ & $\begin{array}{c}\text { Black } \\
\text { share of } \\
\text { each class }\end{array}$ & $\begin{array}{c}\text { Mean } \\
\text { income }\end{array}$ & Mean age & $\begin{array}{c}\text { Mean } \\
\text { educa- } \\
\text { tional } \\
\text { attain- } \\
\text { ment }\end{array}$ \\
\hline Lower class & 33.9 & 37.5 & 13.3 & 87.7 & $R 771$ & 38.4 & 7.6 \\
\hline Middle class & 58.6 & 56.3 & 74.2 & 75.9 & $R 1922$ & 38.7 & 10.0 \\
\hline Upper class & 7.5 & 6.2 & 12.5 & 65.2 & R4434 & 38.6 & 11.3 \\
\hline
\end{tabular}

Source: NIDS 2008. Households identifying themselves as standing on ladder rung 1 and 2 were classified as lower class, those on ladder rung 3 and 4 were classified as middle class and those on the top two ladder rungs were classified as upper class. The highest identified ladder rung was used to classify the household. The mean age and education attainment relates to the household member with the highest occupational skill level.

According to Table 4, perceptions of socioeconomic position appear to be related to education level and income, but there is no association with age. There appears to be a tendency or desire to occupy a middle rather than an extreme or outlying position in the social distribution. If each rung of the ladder represented the same share of the population, $33 \%$ of the population would be in each of these classes. Indeed, $34 \%$ of the population place themselves on the bottom two rungs, but a much higher than proportional $59 \%$ of the population place themselves on rung three and four and a very low proportion (8\%) see themselves as standing on one of the top two of society's ladder rungs. The bias thus appears to be downwards, i.e. individuals tend to underestimate their position in society.

However, in a country marked by deep and overlapping cleavages between white and black, affluent and poor, highly educated and low skilled, suburbs and townships, the reference-group hypothesis would lead a greater share of South Africans to identify themselves as standing on the middle rung of society's ladder when they are in fact at the top or the bottom.

However, if race continues to serve as a good approximation for these overlapping divides fostered by apartheid, then one would expect to see a distribution of self-identified position that is closer to proportional when looking at the races separately, and this is not the case. For the black population, a slightly higher than proportional share views themselves as standing on the bottom two rungs of the ladder (38\%) and a slightly lower proportion on the middle two ladder rungs (56\%) or the top two rungs $(6 \%)$. Similarly, for the white population a much smaller proportion places themselves at 
the bottom of the distribution (13\%), while $74 \%$ see themselves on the middle two ladder rungs and only $13 \%$ think that they occupy the top two rungs of society. This shows that even the white population tends to underestimate their own position in society. This is in line with Phadi and Ceruti's (2011) research that showed that residents of Soweto preferred to see themselves as positioned in the middle of the social distribution, buffered from both sides by a more privileged and less privileged group.

TABLE 5: Self-reported social class in South Africa, 1995, 2001 \& 2006

\begin{tabular}{|l|c|c|c|}
\hline Social class & $\mathbf{1 9 9 5}$ & $\mathbf{2 0 0 1}$ & $\mathbf{2 0 0 6}$ \\
\hline Lower class & 42.5 & 26.4 & 43.9 \\
\hline Working class & 24.1 & 30.8 & 18.9 \\
\hline Lower middle class & 16.6 & 21.0 & 19.5 \\
\hline Upper middle class & 15.4 & 18.5 & 15.2 \\
\hline Upper class & 1.4 & 3.2 & 2.4 \\
\hline
\end{tabular}

Source: WVS 1995, 2001 and 2006

The questions in NIDS about position on a ladder rung is interesting partly because it disassociates the assessment of social position from the terms commonly use to sort the population into social classes. For the same reason, such analysis cannot engage directly with the literature on selfassessed or subjective class. Consequently, we also consider self-identified class based on the World Value Surveys of 1995, 2001 and 2006. Contrary to the rest of the paper, this analysis is based on individuals not households. Table 5 shows that the majority of South Africans consider themselves to be lower or working class. Those who identify themselves as middle class (including both the lower or upper middle class categories) grew from 32\% in 1995 to $40 \%$ in 2001 before dropping to $35 \%$ in 2006. A small minority of respondents consider themselves to be upper class in contemporary South Africa.

According to the 2006 WVS those who identify themselves as lower class appears to be a distinct group with lower education and income levels. This group is also almost entirely black (97\%). The distinction between those who identify themselves as working class or lower middle class appears to be more subtle, with similar age profiles, income levels, educational attainment and racial shares. The lines between upper middle class and upper class are also blurred with similar educational attainment, but with a slightly lower income level, lower age and higher black share for the upper class.

This work confirms earlier results by Seekings (2007) for a sample of individuals in the Cape Town metropolitan area. He shows that regressions with individual characteristics such as education and occupation can only explain a small proportion of the overall variation in subjective self-reported class and concludes that 'the relationship between subjective and objective class was not tidy' (1997:30).

\subsection{Comparing cross-section estimates with rival approaches}

We examine differences in these four approaches. Using the first two waves of NIDS we consider stability by estimating the share of the households that were identified as the middle class in 2008 
who were also middle class in 2010 for each of the four approaches. Middle class categorisation is most stable when using occupational skill (76\%). We find that $62 \%$ of households classified as middle class according to their own assessment continue to see themselves to be on the middle two rungs (rung 3 and 4) on the social ladder in 2010. Only 59\% of those households classified as middle class according to the income approach remain in the same category in 2010 and only $49 \%$ of those households categorised as middle class using the vulnerability approach continue to be classified as middle class in 2010. These fluctuations are much larger than would be expected over a two year period, especially given that the analytical frameworks assume class to be reasonably stable and permanent.

Viewing the vulnerability, occupation and income approaches as approximations of objective social status, we also examined the misalignment between subjective and objective social status in more depth. The individual level data in NIDS showed a greater tendency to underestimate social standing amongst blacks - controlling for occupation, household income and education. This is in line with the qualitative work of Khunou (2012) and Krige (2012) suggesting that some young, educated and affluent black South Africans describe their membership of the middle class as tentative and conditional. The reluctance to use the middle class label could be attributed to the category's strong historical association with being white. Alternatively, this evidence of greater vulnerability may link to Nieftagodien and Van der Berg's (2007) conclusion that the black middle class has a substantial asset deficit compared to other members of the middle class. It appears that black South Africans remain more vulnerable than white South Africans - even after earning a good degree and securing a well-paying job. Accumulated wealth and assets act as a buffer, so a deficit in assets and savings will leave the household more exposed. The vulnerability approach provides further evidence in support of this perspective. When using the vulnerability approach to define classes white South Africans are absent from the lower classes and there are only negligible share of blacks who are classified as upper class.

We use the 2006 World Value Survey to analyse the correlates of self-identified class. Using regression analysis it appears that the traditional, so-called "objective" dimensions of class can explain only a small share of how individuals self-identify into classes. Our analysis suggests that a multi-dimensional living standards index has the most powerful association with self-identified class and explains about $22 \%$ of the observed variation in self-identified class. Years of education is also significant, but only explains $8 \%$ of the observed variation in self-reported class. Occupations and the manual-cognitive content of work both have a significant association with self-reported class, but do not explain much of the variation. Race did not have a significant association with self-reported class. However, the explanatory power decreases considerably when considering the black sample on their own.

There was no link between class identification and views on work. The middle class was also not associated with a less parochial identity (i.e. whether individual sees himself or herself as world citizen or part of a tribe, community, South Africa). Surprisingly, there is not much evidence of a role for values: independence, financial prudence and imagination were significantly associated with the likelihood of respondents classifying themselves as middle class, but these values did not contribute much in terms of explanatory power nor was there a significant association between these values and the likelihood of identifying as middle class amongst the black sample. The only noteworthy 
exception to this rule is our finding that black South Africans who see religion as important are significantly more likely to describe themselves as middle class.

Similar to the findings of Lopez-Calva, Rigolini and Torche (2012), we find little empirical basis for the widely held belief that certain values and attitudes are robustly and significantly associated with the middle class. This also resonates with the findings of Mattes (forthcoming) that show virtually no significant relationship between the tendency to self-classify as middle-class and patriotic or democratic values.

\section{Comparing trends in the middle class for rival approaches}

To examine how these indicators of class differ, we implement each of these rival approaches for the three waves of NIDS and also for the 1993 Project for Statistics on Living Standards and Development data set (PSLSD). Unfortunately, the 1993 PSLSD has a large number of missing values for occupation and there was no comparable question on income rung, therefore we cannot compare these two definitions of class across the entire period from 1993 to 2012. To ensure comparability across the two sets of surveys, we had to implement a simplified version of the vulnerability model ${ }^{10}$ (method described in section 4.2), using a linear probability model instead of a probit. These coefficients are then used to predict vulnerability with the PSLSD data. Implicitly this approach is reliant on the contestable assumption that the structural determinants of vulnerability have remained constant over this period.

We implement the income approach by adjusting the cut-offs estimated in the 2008 NIDS for inflation. We compare these trends in class based on occupation, income and vulnerability in 1993, 2008, 2010 and 2012 to self-reported class according to the World Value Surveys in 1995, 2006 and 2013.

The graph below compares the proportion of black South Africans who belong to the middle class when using rival approaches to defining class. Based on occupation there has been almost no increase in South Africa's black middle class share between 2008 and 2012; it decreased slightly from $31.8 \%$ to $28.8 \%$ between 2008 and 2010 and recovered to $30.8 \%$ in 2012. Because we do not have estimates for 1993 for occupational class and because the estimated trend is very flat, we do not include these numbers in the graph below.

Graph 1 shows a dramatic increase in the proportion of black South Africans classified as middle class based on both the income and the vulnerability approach, but with a more pronounced rise in the black middle class according to the vulnerability approach than when using an income measure. The steep rise in the black middle class shown by the vulnerability approach (from $7.4 \%$ in 1993 to $39.0 \%$ in 2012) may be partly due to improvements in the circumstances and characteristics associated with greater financial security such as educational attainment, access to clean water and

\footnotetext{
${ }^{10}$ The model is similar to the one we implement in 4.2, but we use a more parsimonious asset index because we are restricted to assets that occur both in the 1993 PSLSD and the NIDS panel. We implement asset terciles (using access to clean water, adequate sanitation, electricity, fridge, TV or radio and stove to derive an asset index).
} 
electricity and ownership of stoves and fridges. When class is measured based on per capita household income cut-offs (as described in section 4.3), the increase in the black middle class is less pronounced than in the case of the vulnerability approach, but the rise remains sharp from $15.9 \%$ in 1993 to $34.2 \%$ in 2012.

Figure 1: Comparing trends in rival approaches for defining the middle class for 1993, 2008, 2010, 2012 (or closest years)

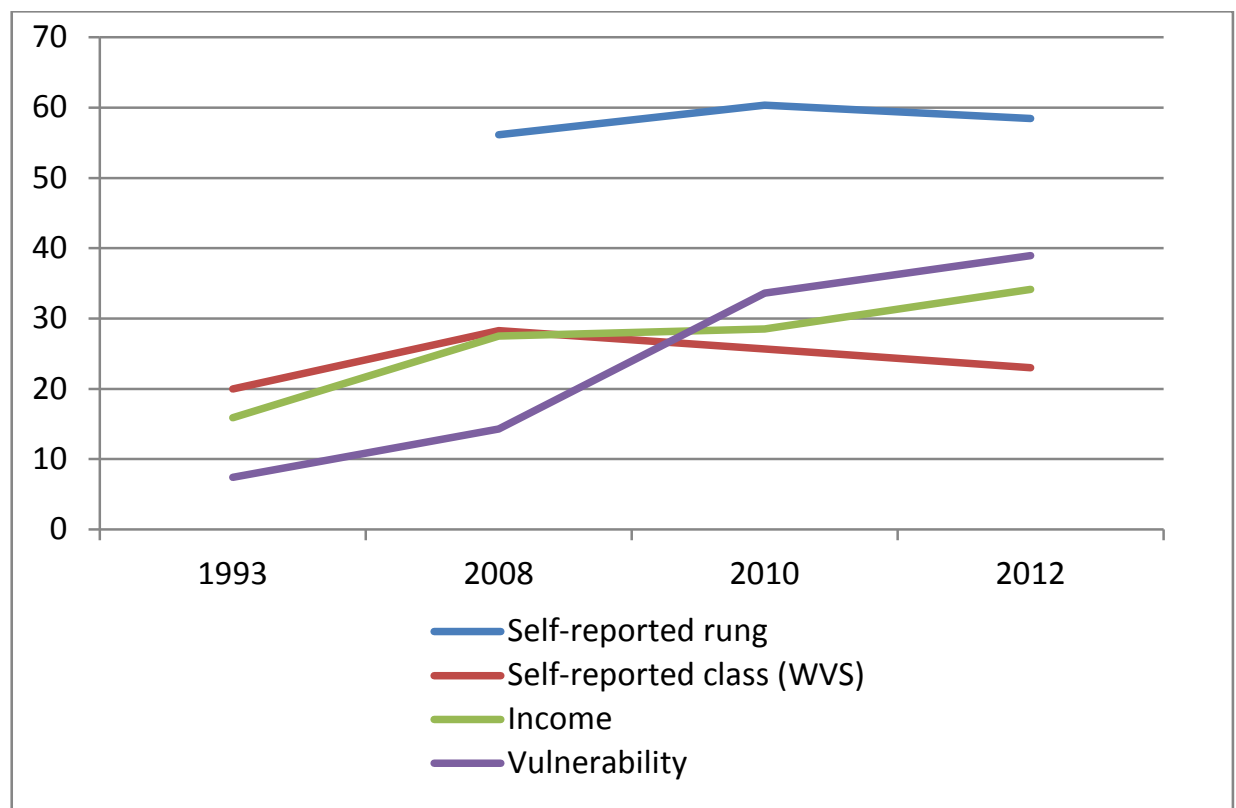

NOTES: National Income Dynamics survey 2008, 2010 and 2012 and SA World Value Surveys for 1995, 2006 and 2013. We report interpolated World Value Survey values for comparison with NIDS 2010 estimates.

It is illuminating to compare these more 'objective' indicators to trends in how individuals described their own social position. As reported before, we find that overwhelmingly individuals tend to place themselves in the middle of the income distribution, with about $60 \%$ of respondents identifying themselves to be on the middle two rungs of the income distribution. Although one should be cautious to compare the NIDS estimates with those from the World Value Surveys, the magnitude of the gap is wide enough that it is not controversial to observe that many South Africans who think of themselves as being in the middle of the income distribution do not describe themselves as middle class, indicating that this is a more loaded term and is not simply seen as referring to those who see themselves occupying the middle of the income distribution. This wide gap between the proportion of South Africans who classify themselves as occupying the middle position in the income distribution and the much smaller proportion classifying themselves as middle class holds not only for the black subsample (depicted in the graph), but for all South Africans.

Because the self-reported rung question is based on a relative classification of social position and income, one would not expect it to be responsive to absolute improvements in income or security. However, one may expect some correspondence between the self-reported class and our 'objective' class indices such as the vulnerability approach and the income measures. It is therefore interesting to see that the sharp observed rise in the black middle class shown by these 'objective' indicators is not mirrored in the proportion of black South Africans who classify themselves as middle class over this period. This is in line with previous studies showing that individual conceptions of what class 
membership means are slow to change, but more significantly, that there is a sluggish response of identity to changes in the individual's 'class markers'. This could be related to an inherent reluctance to reclassify oneself, especially in a context where class has a strong link to social identity or may confirm Inglehart and Welzel's (2005) ideas around the socialisation aspect of class and the dominant role of childhood experiences and circumstances (Inglehart and Welzel, 2005).

\section{Conclusion}

Our analysis shows considerable variation in who is classified as middle class based on the different definitions that we employ. While there is some overlap, there are also substantial differences in who is identified as the middle class based on whether we implement the occupational, income, vulnerability or subjective social status approach to discern class membership. Reported income, occupation and vulnerability measures appear to have a weak relationship with self-identified class. This is in line with the work of Schlemmer (2005), who argued that the South African middle class lacks cohesion and that skilled and affluent individuals are reluctant to self-identify as middle class. Qualitative work by Khunou (2012) and Krige (2012) suggests that well-educated, skilled black South Africans appear uncomfortable with the 'middle class' tag and are reluctant to describe themselves in this way - seemingly at least partly because of the category's strong historical association with being white and consequent perceived tensions between their racial and cultural identity and persistent ideas around what being 'middle class' represents.

The country's apartheid past and the post-apartheid state's responses to this obviously strongly influenced both the nature of the middle-class in contemporary South Africa and individual behaviour of members of this class. The perceived vulnerability of sections of the black middle class has much to do with the fact that they lack the assets that allow them to fully adopt a middle class lifestyle, but also with the tenuousness of their middle class status. Stronger economic growth would perhaps have engendered greater confidence in their ability to maintain their status, but modest economic growth over most of the post-transition period that moderated the growth of the middle class along with some economic shocks have probably undermined such greater security.

State policies greatly influenced the growth and the nature of the black middle class. Economic empowerment created a small but visible group of black capitalists. More important in numerical terms was upward social mobility in both the public and private sectors, with affirmative action policies lending support. The beneficiaries were those best placed to enter the higher rungs of the labour market. The immediate post-apartheid period and some catch-up allowed a large expansion of this group, but the weak performance of both the education system and the economy does not augur well for similarly rapid expansion in future. This creates an interesting political dynamic, with younger cohorts expecting more well-remunerated jobs than the education system and labour market may be able to provide.

Identity is a crucial factor in the pursuit of greater social cohesion and political stability. If the racial gap in earnings and education is decreasing, but racial differences continue to loom large in the minds of South Africans, the growth in the black share of middle class professions or the black share of income will not translate to a more integrated and less polarised social and political landscape. This may also be an important finding for the wider literature, demonstrating that it is vital to move 
beyond the surface and question and explore how class categories are perceived and used. Research on class should consider not only objective social status, but also subjective social status - especially in the light of its importance in mediating some of the key economic and political benefits associated with the middle class. 


\section{References}

Argent, J, Finn, A, Leibbrant, M \& Woolard, I, 2009. Poverty: Analysis of the NIDS Wave 1 Dataset. NIDS Discussion Paper No. 13, South African Labour and Development Research Unit (SALDRU), School of Economics, University of Cape Town.

Atkinson, A \& Brandolini, A, 2011. On the identification of the "middleclass". Society for the study of income inequality (Ecineq), Working Paper $\mathrm{Nr}$ 2011-217.

Beckett, A, 2010. Is the British middle class an endangered species? The Guardian, July 24, 2010, p. 28. http://www.guardian.co.uk/uk/2010/jul/24/middle-class-in-decline-society.

Birdsall, N, 2010. The (Indispensable) Middle Class in Developing Countries; or, The Rich and the Rest, Not the Poor and the Rest. Center for Global Development. Working Paper 207.

Birdsall, N, Graham, C \& Pettinato, S, 2000. Stuck in the Tunnel: Is Globalization Muddling the Middle Class. Center on Social and Economic Dynamics. Working Paper No 14.

Carlsson, C, 1958. Social mobility and class structure. Gleerup, Lund.

Ceruti, C. 2013. A proletarian township: Work, home and class. In Alexander, P, Ceruti, P, Motseke, K, Phadi, M \& Wale, K. Class in Soweto. Scottsville: University of KwaZulu-Natal Press.

Cole, $G, 1955$. Studies in class structure. Routledge, London.

Durkheim, E, 1933. The Division of Labour in Society. Free Press, Glencoe.

Easterly, W, 2001. The Middle Class Consensus and Economic Development. Journal of Economic Growth, 6, 317 - 335.

Edgell, S \& Duke, V, 1991. A measure of Thatcherism: A sociology of Britain. Harper Collins, London.

Esteban, J \& Ray, D, 1994. On the measurement of polarization, Econometrica, 62, (4).

Esteban, J, Gradín, C \& Ray, D, 1999. Extensions of the measure of Polarization, with an application to the income distribution of five OECD countries. Working Paper No. 218, Maxwell School of Citizenship and Public Affairs, Syracuse University, New York.

Evans, G \& Mills, C, 1999. Are there classes in post-communist societies? A new approach to identifying class structure. Sociology, 33(1), 23-46.

Glassman, RM, Swatos, WH \& Kivisko, P, 1993. The noble character and flaws of the middle class. Greenwood Publishing Group, Westport, CT.

Goldthorpe, JH, 1987. Social mobility and class structure in modern Britain. Clarendon Press, Oxford.

Goldthorpe, JH \& Erikson, R, 1993. The constant flux. A study of class mobility in industrial societies. Clarendon Press, Oxford.

Goldthorpe, John H \& McKnight, A, 2004. The economic basis of social class. CASEpaper, 80. Centre for Analysis of Social Exclusion, London School of Economics and Political Science, London, UK.

Hertova, D, Lopez-Calva, LF \& Ortiz-Juarez, E, 2010. Bigger...but Stronger? The Middle Class in Chile and Mexico in the Last Decade. Research for Public Policy, Inclusive Development, ID-02-2010, RBLAC-UNDP, New York.

Inglehart, R \& Welzel, C, 2005. Modernization, Cultural Change and Democracy: The Human Development Sequence. Cambridge: Cambridge University Press.

Jackman, RW, 1974. Political democracy and social equality: a comparative analysis. American Sociological Review, 39(1), 29-45.

Jackman, MR \& Jackman, RW, 1973. An interpretation of the relation between objective and subjective social status. American Sociological Review, 38, 569-582.

Khunou, G, 2012. What middle class? The shifting and dynamic nature of social life: life histories of two women from Gauteng. Mimeo.

Krige, D, 2012. Being black and middle class in contemporary Johannesburg: the narrated life story of MR. Mimeo.

Lopez-Calva, LF \& Ortiz-Juarez, E, 2011. A vulnerability approach to the definition of the middle class. Policy Research Working Paper Series 5902, The World Bank. 
Lopez-Calva, LF, Rigolini, J. \& Torche, F. 2011. Is There Such Thing As Middle Class Values? Class Differences, Values and Political Orientations in Latin America, The World Bank Policy Research Working Paper 5874.

Mattes, R. Forthcoming. South Africa's Emerging Black Middle Class? Journal of International Development, forthcoming.

Marx, K, 1972. Economic and philosophic manuscripts of 1844: Selections. In Tucker, RC (ed). The Marx-Engels Reader. W.W. Norton, New York.

Marx, K \& Engels, FC, 1968. The Communist Manifesto. In Selected Works. International Publishers, New York.

Nieftagodien, S \& Van der Berg, S, 2007. Consumption patterns and the black middle class: The role of assets. Stellenbosch Economic Working Paper 02/07. Bureau for Economic Research \& Department of Economics, University of Stellenbosch. Stellenbosch.

Pakulski, J, 2005. Foundations of a post-class analysis. In Wright, E.O. Conclusion: If class is the answer what is the question. Approaches to class analysis. Cambridge: UK.

Phadi, M \& Ceruti, C, 2011. Multiple meanings of the middle class in Soweto, South Africa. African Sociology Review, 15(1), 88- 108.

Raynor, J, 1969. The middle class. Longman, London.

Rivero, C, Du Toit, P \& Kotze, H, 2003. Tracking the development of the middle class in democratic South Africa. Politeia 22(3), 6-29.

Schlemmer, L, 2005. Lost in Transformation? South Africa's Emerging Middle Class. Centre for Development and Enterprise. CDE Focus Occasional Paper No 8.

Seekings, J, 2003. Do South Africa's Unemployed Constitute an Underclass? Centre for Social Science Research Working Paper No. 32.

Seekings, J, 2007. Perceptions of class and income in post-apartheid Cape Town. CSSR Working Paper no.198, Centre for Social Science Research, University of Cape Town.

Seekings, J, 2009. The Rise and Fall of the Weberian Analysis of Class in South Africa between 1949 and the early 1970s. Journal of Southern African Studies, 35(4), 865-81.

Seekings, J \& Nattrass, N, 2005. Race, Class and Inequality in South Africa. Yale University Press, New Haven.

Simpson, J \& Dore, B, 2008. Black Diamonds: the new South African middle class. Management Today, 24(4), 43-47.

Statistics South Africa, 2009. Profiling South Africa middle class households, 1998-2006. Statistics South Africa Report 03-03-01, Statistics South Africa, Pretoria.

Stouffer, SA, Suchman, EA, de Vinney, LC, Star, SA \& Williams, JR, 1949. The American Soldier: Adjustment during Army Life. Princeton University Press, Princeton, NJ.

Torche F \& Lopez-Calva, L, 2011. Stability and Vulnerability of the Latin American Middle Class. In Newman, K (ed), Dilemmas of the Middle Class around the World, Oxford University Press.

Udjo, EO, 2008. The Demographics of the Emerging Black Middle Class in South Africa. Bureau of Market Research, Research Report No 375, University of South Africa, Pretoria.

Van der Berg, S. 2010. The demographic and spatial distribution of inequality. In Bernstein, A (Ed.), Poverty and Inequality: Facts, Trends and Hard Choices. Centre for Development and Enterprise Round Table Paper Number 15. Centre for Development and Enterprise, Johannesburg.

Visagie, J \& Posel, D, 2013. A reconsideration of what and who is middle class in South Africa, Development Southern Africa, 30(2), 149-167.

Weber, M, 1961. Essays in sociology. Routledge and Kegan Paul, London.

Wright, EO. 1979. Class, crisis and the state. Verso, London.

Wright, EO. 1980. Class and occupation. Theory and Society, 9, 177-214.

Wright, EO. 1989. The debate on classes. Verso, London.

Yu, D. 2008. The comparability of Income and Expenditure Surveys 1995, 2000 and 2005/2006. Stellenbosch Economic Working Papers 11/2008. 